\title{
IN-YeR-FACE: TARIHSEL VE TEORIK BiR İNCELEME
}

IN-YER-FACE:

A Historical

AND THEORETICAL

INVESTIGATION

\section{EREN BUĞLALILAR}

Özet

Bu makalede, 90'lı yılların ortasında Britanya'da In-yer-face Theatre (IYFT) adıyla anılan ortaya çıkan tiyatro eğilimini tarihsel bağlamına oturtuyor, Britanya dramındaki bu eğilimin neoliberal projeyle ve Britanya'daki sınıf mücadelesinin ve sınıf bilincinin azalmasıyla yakın ilișkili olduğunu söylüyorum. Oyun yazarlarının sınıf siyasetiyle yașadığı kopușun ve șiddete karșı duydukları hevesin, güçlü bir apolitikleștirme sürecinin yarattığı küçük-burjuva dünya görüșünün bir sonucu olduğunu ileri sürüyorum. Makalenin ikinci bölümünde IYFT'nin teorisine eğiliyorum ve șimdiye kadar iddia edilenlerin aksine, yazarlarının küçük-burjuva eğilimleriyle uyumlu olarak, șiddeti estetikleștirdiklerini ve onun siyasi içerimlerini gizlediklerini iddia ediyorum.

\section{Abstract}

In this article, I place the In-yer-face Theatre (IYFT), which emerged in Britain in the mid-90s, into its historical context, stating that the emergence of such a tendency in British drama is strongly related with the rise of the neoliberal project and with the fall of class struggle and class consciousness in Britain. I argue that the dramatists' break with the class politics and their enthusiasm towards violence is the result of their petitbourgeois world view created by a strong depoliticization. In the second part of the article, I am concerned with the theory of IYFT and contrary to what is argued thus far, I state that the this tendency aestheticizes the violence and conceals its political implications in accordance with the petit-bourgeois tendencies of its dramatists. 
ürkiye'deki tiyatro teorisinin ana gövdesini pratiksiz teoriler olușturuyor. Eldeki son derece kısıtlı malzemenin büyük çoğunluğu, Batı tiyatrosunun yetiștirdiği uygulamacıların ve teorisyenlerin eserlerinden derlenmiș durumda ve dahası, güncel değil. Oysa sanatsal ve politik gündem devamlı olarak değișiyor. Ülkede tiyatro "peygamberlerine" ilișkin metinlerin niceliğine denk bir pratik de olmadığından, teori bu pratiklerin çokça üretildiği kaynaklardan ithal edilmek durumunda kalınıyor ve genellikle pratikten önce ülkeye geliyor.

Ancak istisnalar da var. Brecht'in tiyatrosu Türkiye'de sınıf mücadelelerinin hız kazandığı bir dönemde, eksikli de olsa teori ve pratik düzeyinde ülkeye aktarılmıș, yeni oyunların yazıımasına önayak olmuștu. Daha güncel bir örnekte ise ișin seyri değiști: Türkçede hakkında pek çok bilgiye erișilebilen tiyatro akımlarına ilișkin tutarlı pratikler mevcut değilken, hakkında derinlikl teorik metinler bulmanın mümkün olmadığı "in-yer-face theatre" ("yüzünüze karșı tiyatro" diye çevrilebilir; bundan sonra "IYFT" olarak geçecek) muamması, Tiyatro DOT'la 2005 yılında ülkeye ithal edildi. Tabii, IYFT'nin İngiltere'deki zirve günleri çoktan sona ermiș, artık Almanya üzerinden Kıta Avrupa'sına pazarlanıyordu. Yukarıda da bahsettiğim üzere, ilginç olan IYFT'nin ithal edilmesi değil de, pratiğinin teorisinden önce ülkeye gelmesidir.

Bu eğilimin geç de olsa aydınlatılması Türkiye'deki tiyatrocular için yeni sayılabilecek bilgilerin aktarılmasına imkân sunuyor. Bașka bir mesele de, IYFT'nin ekonomik ve siyasi bir darbenin ardından sanatın seyrinin nasıl değiștiğine model olabilecek niteliğini tartıșmaktır. Britanya tiyatrosunun 30 yıllık döneminde olup bitenler, Türkiye'de tiyatronun 12 Eylül fașist darbesinin ardından geçirdiği değișimle karșılaștırılabilecek bir örnek sunuyor. Ne var ki, daha en baștan ișin teorik boyutunda vaziyetin biraz karıșı olduğunu söylemekte fayda var.

Tıpkı Aristoteles'in Poetika'sı, yahut daha güncel bir örnek verecek olursak, Martin Esslin'in Absürd Tiyatro adlı eseri gibi, IYFT'ye ilișkin teorik çalıșmalar da bu alanda belli bașlı bazı tiyatro eserlerinin ortaya çıkıșından sonra yazıldı. 1995 yılında Sarah 
Kane'in Blasted (Harap) adlı oyununun sahnelenmesiyle, yazarın 1999'da intihar etmesi arasındaki 4 yıl, IYFT'nin altın yılları olarak adlandırılıyor. IYFT isimlendirmesi de bir tiyatro eleștirmeni ve gazeteci olan Aleks Sierz'in 2001 yılında yazdığı kitapla kullanımaya bașlandı.' Onun getirdiği bu isimlendirme en sık kullanılanı, ama 'Cruel Britannia', 'Cool Britannia', 'British Brutalism', 'New European Drama' (Vahși Britanya, Soğukkanlı Britanya, Britanya Brutalizmi) ya da yalnızca '1990'lardaki Britanya Dramı' isimlendirmeleri hiç de az değil.

Ancak asıl zorluk bu da değil. Mesele, dört beș seneyi kapsayan bir zaman diliminde kimi yazarların kimi oyunlarında benimsediği bir eğilimin (ki burası önemli, Sierz'in de dediği gibi, bir IYFT yazarlığı yok) șu ya da bu isimle etiketlenmesinden çok, böyle bir etiketlemenin mümkün olup olmadığı. IYFT riskli ama kârlı bir yatırım olarak Britanya'dan ithal edilirken bu markayı kullanmak Kıta Avrupası'ndaki tiyatro sahiplerinin ișine gelmiș olabilir. Tek tek oyunların getirilmesindense, belirli bir markanın üst bașlık olarak kullanılması gerçekten de etkili oldu. ${ }^{2}$ Ama ișin çehresi, bu eğilimin isim babası olan Sierz'in kendisini sorgulayan makalesini okuduğumuzda değișiyor.

Sierz, makalesinde IYFT gibi bir kavramı neden tercih ettiğini özetledikten sonra bir özeleștiriye girișiyor:

Kitap içten içe in-yer-face'in çağdaș tiyatroya ait bir marka olduğunu ve dünyayı in-yer-face içindeki ve dıșındaki yazarlar, in-yer-face içindeki ve dıșındaki oyunlar diye bölebileceğinizi ima ediyorduysa da, gerçeklik bașkaydı. $^{3}$

Sierz'in özeleștirisi aslında temelde tek bir noktaya odaklanıyor: indirgeme. Britanya'daki oyun yazarlığı her dönem büyük bir çeșitlilik arz etmekteydi. Bunların tümünü bir araya getirip bütünlüklü bir anlatı olușturmak her zaman mümkün olmadığı için, bir "içindekiler listesi" hazırlayıp, buna uyan oyunları bir araya getirmek en mantıklı yoldur. IYFT edebiyatıyla daha hașır neșir oldukça anladığım bir șey de, bu içindekiler listesine tüm oyunlarıyla dahil olacak bir yazarın yokluğudur. Dahası, farklı yazarların
1 Bkz. Aleks Sierz. In-Yer-Face Theatre: British Drama Today (Faber, 2001).

2 IYFT'nin ticari olarak ne ifade ettiğini, yazı boyunca sık sık atıfta bulunacağım Sanja Nikcevic. "British Brutalism, the 'New European Drama', and the Role of the Director", NTQ 21:3 (Ağustos, 2005) adı ıçalıșmanın net bir șekilde ortaya koyduğunu söylemeliyim.

${ }^{3}$ Sierz, Ön.ver. s. 29. 
oyunlarından yapılacak bir IYFT listesi de bir akıma değil, kimi öğelerle sınırlı kalmıș bir eğilime ișaret ediyor. Zaten "[K]esinlikle bazı in-yer-face anları vardı ancak yine kesinlikle hiçbir katıșıksız in-yer-face yazarı, sorunsuz in-yer-face oyunu ve bir in-yer-face hareketi yoktu"4 diyen Sierz de bunu vurguluyor.

Yine de ister bir eğilim, ister bir akım olsun, etraflı bir eleștirisine girișmek istiyorsak, öncelikle onu adlandırmamız gerekiyor. Ben yaygın kabul görmesi bakımından Sierz'in adlandırmasını kabul edeceğim. Bununla birlikte, IYFT adlandırmasını bugüne kadar kabul gördüğü marka, akım, hareket içeriğiyle değil, Thatcher sonrası Britanya'sı oyun yazarlığında ortaya çıkan küçük-burjuva bir eğilimin en somut hali olarak ele alacağım. Tiyatroda ortaya çıkan tüm eğilimler gibi, IYFT de tarihsel ve ideolojik bir birikimin (ya da birikimsizliğin) dıșavurumuydu ve yine çoğu eğilim gibi bir kriz anında ortaya çıktı. Dolayısıyla teorisiyle hașır neșir olmaya bașlamadan evvel, IYFT'nin ortaya çıkıșını, bu eğilime duyulan ilginin tarihsel ve toplumsal zeminiyle birlikte ele almak en doğrusu olacaktır.

\section{MaZide Kaybedilen İșçi Sinıfı}

Oyun yazarlığı ve yazılı metinlere yaslı tiyatro dünyada uzun süredir sorunlar yașıyor. Bu sürecin bașlangıç noktası olarak tiyatronun avangardları gösterilir. Yine de bir sanat akımının ortaya çıkıșıyla, piyasadaki hâkim ifade biçimi olması farklı șeyler ve bunda genellikle belirleyici etmen, sınıf mücadelesinin aldığı biçim oluyor. Örneğin etkin ve örgütlü bir halk hareketinin olduğu, solun ideolojik hegemonyasını egemenlere dayattığı bir toplumda sanatçının kendisini bu hareketlere bağlaması kolay olabiliyor. Halk hareketlerinin yenilgiye uğradığı uzun kriz dönemlerinde ise sanatçıların genel tavrı bireycilik, varoluşçuluk, ilkelcilik, feminizm ve milliyetçilik gibi hareketlere eklemlenmek ya da (italyan Fütüristleri örneğinde olduğu üzere) tümden egemenlerin saflarına geçmek olabiliyor. 
yeni eğilimin 2. Paylașım Savașı sonrasında emperyalist ülkelerde yavaș yavaș baskın hale geldiğini iddia etmek yanlıș olmaz. Avrupa'da Marshall planı doğrultusunda inșa edilen refah devletinin emekçi profilini değiștirmesi, emperyalizmin yeni evresinde bağımlılık biçimlerinin yeni șekiller alması, Amerika Birleșik Devletleri'ndeki muhalif yapılanmaların bir kısmının "çiçek çocuk" olmanın ötesine geçemeyiși bunda etkin oldu. 1960'lar ve '70'ler boyunca sosyalizme dönüșemeden kalan demokratik devrimlerin ve ABD destekli darbelerin yarattığı hayal kırıklığının, emperyalist ve sömürge ülkelerin kültür sanat çevresindeki etkisi de göz ardı edilemez derecede büyük oldu elbette. ${ }^{5}$

Tüm bu sarsıntılar küçük-burjuvazi için oldukça bunaltıcı oldu. Sınıf siyasetinden uzaklaștııımanın, pratikten kopartılmanın bedelini tüm kültürel sermayelerini teoriye yatırarak ödemeye çaııștılar. Kapitalizmin yıkılacağına ilișkin bir umutsuzluk, giderek içine kapanan teoriyle el ele ilerledi. Performans teorisinden ya da 1970 sonrası tiyatrosundan bahseden metinlerin bir "kutsal metne", Lyotard'ın "Postmodern Durum" adlı makalesine sürekli olarak atıf yapmaları boșuna değildir. Belirsizliğin, "büyük anlatılar"ın çöküșüne duyulan imanın, piyasa ekonomisini ve yayılan sermayeyi kutlamanın; üretim sürecinin yerini tüketim sürecinin, ișçi sınıfının yerini burjuva demokrasisini cilalamaya uğrașan sivil toplumun alıșının en çok etki yaratan ifadesi olan bu metin, toplumu değiștirmeye yönelik herhangi bir umudu ve isteği kalmayan küçük-burjuvazinin sorumluluklarından arınıp düzene uyum sağlamasının bir manifestosuydu.

Teori, sosyalist sanatı otoriterlik ve ortodokslukla suçlarken; pratik, șansını sınıf mücadelesinin dıșında, bașka mecralarda denemeye yöneldi. 2. Paylașım Savașı'nın bitmesiyle birlikte bu sefer SSCB ile ABD arasında gerginleșen ilișkiler, kültür alanında sınıf siyasetinden tamamen kopuk soyut bir sanatın ABD tarafından kollanmasına, en azından karșısına zorluk çıkarılmadan icra edilmesine imkân tanıdı. ${ }^{6}$ 1960larda Carolee Schneeman sahne üzerinde pornografik-erotik gösteriler yapıyor (Schneeman'ın en bilinen gösterisi, 1963 tarihli The Meat Joy'du), Vito Acconci performanslarında katılımcılara mastürbasyonunu izlettiriyor, Chris

\footnotetext{
${ }^{5}$ Aijaz Ahmad, In Theory Classes, Nations and Literatures. (Teoride Sinıflar, Uluslar ve Edebiyatlar, Verso, 1992) adılı kitabında bu sürecin derli toplu bir dönemleștirmesini sunmaktadır. Kitap Türkçeye de çevrildi, fakat ne yazık ki inanılmaz çeviri hatalarılyla dolu olduğunu söyleyerek okuru uyarmak isterim.

${ }^{6}$ Günter Berghaus'un da belirttiği üzere, bu dönem emperyalist ülkelerde en çok finanse edilen tiyatronun absürd tiyatro olması bir tesadüf değildir.
} 
Burden canlı bir performansta (Shoot, 1971) bir arkadașına kendisini kolundan vurduruyor, Marina Abramoviç seyirci karșısında kendine eziyet ediyor (Thomas Lips, 1975), Bob Flanagan elinde çekiç, penisine çivi çakıyordu (1989). Elbette bu performansların "kadın bedeni üzerindeki tahakkümü kırmak", "sanatsal dehanın mazoșizmle olan bağını göstermek" ve "seyirciyi röntgenci konumuna düșürerek onda bir farkındalık uyandırmak" gibi seçkin amaçları olduğunu belirtmeye gerek yok. Bunların konumuzla ilgili olan yönü, tüm bu pratiklerin ortak özelliğinin gösterim sanatlarındaki yepyeni bir eğilime, yani söze değil bedensel ifadeye dayalı olan, prova ve belirlenim yerine "șans"ı geçiren bir metinsiz gösterim alanına ișaret etmeleri ve yüksek oranda bedensel șiddet içermeleridir.

Performans, tiyatronun “-mıș gibi yapan” konumuna savaș açmıșken ve yerine bedeni, süreci, olușu, sahiciliği ve seyirciyle birebir etkileșimi ikame etmeye çalıșırken, tiyatro cephesinde de önemli bir gelișme yașanıyordu. Grotowski, Barba ve Brook gibi isimler Artaud'nun açtığı yoldan ilerleyerek yeni bir "apolitik" tiyatro yarattılar. Robert Wilson imgelere ve bedenlere dayalı, "mesajsız" bir tiyatro inșa etti. Performansın yolu 80'ler ve 90 'larda tiyatroyla yavaș yavaș kesișirken, performans teorisinin kült isimlerinden olan Richard Schechner yeni paradigmanın artık tiyatro değil, performans olduğunu söylüyordu. ${ }^{7}$ Gerçekten de yeni eğilim bir oyun metninin sahnelenmesi değil, sahne için yazılmamıș metinlerin ve Shakespeare gibi klasiklerin kes-yapıștır ya da uyarlama yöntemiyle sahne metni haline getirilmesiydi. Kimi örneklerde de ekip, provalar sırasında kendisi bir metin yaratıyordu. 2. Paylașım Savașı sonrasında yönetmen tiyatrosunun ve oyun yazarlığının girdiği yeni yolu Sanja Nikcevic șöyle tarifliyor:

Eğer yașayan oyun yazarı kabul görmek istiyorsa, bir yönetmenin siyasi, cinsel ya da (en önemlisi) estetik yönelimlerini bilmesi gerekiyor. Bu sonuncu [yönelim], bir metnin, yönetmenin vizyonu uyarınca sonu gelmez bir biçimde kesilip yapıștırımasına

7 Simon Shepherd ve Mick Wallis. Drama/Theatre/Performance. (Routledge, 2004). S. 152.

${ }^{8}$ Nikcevic. Ön.ver. s. 256. istekli olmak ya da oyunu, yönetmenin içine ne isterse ekleyebileceği kadar açık bir biçimde yazmak anlamına geliyor. Heiner Müller'in Hamletmakinası ve Büchner'in Woyzeck'i iște bu yüzden yüzyılın ikinci yarısında bu kadar sık sahnelendiler. ${ }^{8}$ 
Hans-Thies Lehmann da 'postdramatik tiyatro' dediği 1970 sonrası eğilimlerin metinlerinde "temsilden daha ziyade bulunuș, iletilenden ziyade paylașılan bir deneyim, üründen ziyade süreç, anlamdan ziyade belirti, bilgiden ziyade enerjik bir dürtü” ${ }^{9}$ bulunduğunu vurguluyordu.

Burjuva sanatının hem teorisi hem de pratiği "postdramatik" tiyatroda ve performansta taze bir soluk buldu. Ama daha da önemli ve konumuzla ilișkili olan olgu, oyun yazarlığının en azından Kıta Avrupası ve Amerika'da bildiğimiz biçimiyle geri plana düștüğüdür. Avrupa Tiyatro Ödülleri adıyla anılan en büyük tiyatro ödüllerinin 1986'dan 2000 yılına kadar (1994'te ödül alan Heiner Müller hariç) yalnızca yönetmenlere verilmesi de bunun kanıtlarından biri.10 Metne tabi olan yönetmenin yerini, yönetmene tabi olan metin alınca, sadece prova ve sahneleme süreçleri değil, oyunların yazılıș süreci de değișime uğradı.

Bu tür tahlillerin her zaman tek tarafı olma, arzu edilenin üzerinde bir genelleme düzeyine ulașarak gerçeği çarpıtma riskleri vardır. Özellikle yirminci ve yirminci birinci yüzyıl sanatı olağanüstü bir çeșitlilik arz etmekteyken, tiyatro alanında tek bir eğilim üzerine kafa yormak, bizi renk körlüğüne götürebilir. Tiyatro üzerine yapılan araștırmaların ve çıkartılan yayınların derinleșmek isterken sınırlı konulara yoğunlașmak zorunda kalması ve bunun sonucunda meselesini diğer biçim ve içerik denemelerinden yalıtılmış olarak incelemesi de bu körlüğü güçlendiriyor. Örneğin HansThies Lehmann'ın Postdramatik Tiyatro adlı kitabını okuyanlar, 1970'lerden sonra, tüm tiyatro sanatında bu eğilimden bașka bir eğilim kalmadığını sanabilir. Performans sanatı konusunda da benzer bir durum söz konusu. Bu nedenle tarih ve teori meselesinde iki kat hassas olmak șart.

Shakespeare'in memleketindeki dram ve tiyatro söz konusu olduğunda, hele hele 1970'lerden bahsediliyorsa, performans sanatının ve postdramatik tiyatronun hâkimiyeti efsaneleri biraz tökezliyor. Kıta Avrupası ve ABD'deki akımların Manș Denizi ve Atlantik'te boğulmasının nedenlerinden birincisi, Britanya topraklarında yüzyıllara dayanan sağlam bir dram sanatı geleneği-

\footnotetext{
${ }^{9}$ Hans-Thies Lehmann. Postdramatic Theatre. Çev: Karen Jürs-Munby. (Routledge, 2006). s. 85.

${ }^{10}$ Nikcevic. Ön.ver. S. 256.
} 
nin, ülkedeki yoğun ticari tiyatro faaliyetiyle bulușmuș olmasıdır. İkincisi, ticari tiyatrolardan ayrı olarak bu dram sanatının proletarya siyasetine çok erken bağlanmasıdır. ${ }^{11}$ Üçüncü ve kanımca en belirleyici olan neden, tüm dünyada yașanan devrimci kalkıșmaların, Britanya'daki siyaseti ve tiyatro faaliyetini 1960 'ların sonundan bașlayıp, 1980'lerin ortalarına kadar yoğun bir biçimde etkilemiș olușudur.

1960'ların sonlarından itibaren Britanya'da Howard Brenton, David Hare, Trevor Griffiths, David Edgar ve John McGrath gibi sosyalist yazarların ve bu yazarların oyunlarını sahnelemeye hevesli Agit-Prop, CAST ve 7:84 gibi tiyatroların ortaya çıkıșı, Türkiye'deki sanat hareketini de andırır biçimde, bu dinamiklere bağlıdır. Özellikle Britanya'da 1970 yılında yapılan genel seçimlerde muhafazakâr Heath hükümetinin bașa gelmesinin ardından militanlașan ișçi ve sendika hareketleri, toplumsal alandaki bu dalgalanmanın güzel bir örneğini olușturuyor.

${ }^{11}$ Richard Stourac ve Kathleen McCreery, Theatre as a Weapon: Workers' Theatre in the Soviet Union, Germany and Britain, 1917-1934 (Routledge \& Kegan Paul, 1986) s. 192'de ilk radikal tiyatroları 1832 yılına tarihliyorlar. Yine kendilerinden 1840larda Rotunda tiyatrosunun da Çartistlerin karargâhı olarak kullanılan ve pek çok Çartist önderin oyunlar yazıp sahnelediği bir merkez olduğunu öğreniyoruz.

12 Tony Cliff ve Donny Gluckstein. The Labour Party: A Marxist History. (Bookmarks, 1996), s. 308-9.
24 Haziran 1971 tarihinde Glasgow'da 100.000 liman ișçisinin greve gittiğini; grevin sonlanmasının hemen ardından hükümetin ișten çıkarmalar yapacağını açıklaması üzerine dört tersanenin derhal ișgal edildiğini; Temmuz 1971'de Londra'daki beș liman ișçisinin tutuklanmasının ardından 44.000 işçinin yasadıșı bir greve gittiğini; 1972 ile 1974 arasında 200'den fazla tersane, fabrika, ofis ve atölyenin ișgal edildiğini ve nihayet, önce 1972'de daha sonra da 1973-74'te madenci grevleriyle hükümetin yerinden edildiğini söylemek, Britanya'daki sosyal mücadele atmosferinin verilmesi açısından önem tașıyor. Marksist tarihçiler Cliff ve Gluckstein, bu süreci “1970 yılında toplam grev günü 10.980.000'e, 1971'de 13.551.000'e ulaștı, 1972'de 23.909.000 güne tırmandı ki bunlar 1920'lerden beri ulașılan en üst sayılardı,"'12 diyerek aktarıyorlar.

Ne var ki, emeğin bu kalkıșması 1974 yılında revizyonist Emek Partisi'nin (EP) iktidara gelișiyle frenlendi. Parti'nin önlemleri, uluslararası emperyalizmin 1974'te bașlayıp 4 yıl süren krizi nedeniyle sıkıntıya düșen Britanya kapitalizmini kurtarmaya yetmeyince, ekonomik kriz siyasi krize dönüștü. EP'nin tavrı, temsil etme görevini üstlendiği ișçi sınıfının militanlığını yıpratan, eylemciliğini 
sekteye uğratan bir tavırdı ve böylesi bir "sol" siyasete duyulan güvensizlik, Britanya halklarını birdenbire muhafazakârlığın, Thatcherizm diye adlandırılacak neoliberal yağmacılığın kollarına bıraktı. 1979 yılındaki genel seçimlerden zaferle çıkan Thatcher, Heath hükümetinin aksine ișçi militanlığının son hamlelerini savușturup ülkedeki manzarayı baștanbașa değiștirecek bir politika bașlattı.

Demir Leydi sendikal hareketleri bitirdi, "refah devleti" projesinin cenaze marșını besteleyerek bir özelleștirme dalgası bașlattı, kültüre piyasa darbesini vurdu, popülist bir söylem ve medya desteğiyle solun ideolojik hegemonyasını yıkmaya giriști. Halktan yana kaygılar güden sanatın ekonomik, toplumsal ve ideolojik zeminini kaydırmak için gerekli ortam böylece hazırlanmıș oldu. Türkiye'deki 12 Eylül fașist darbesiyle Thatcherizm arasında uzak bir akrabalık olduğu kesindir. Bugün tiyatro dünyasında in-yerface oyunları diye bilinen oyunların yazarları, çocukluklarını iște bu bilinç yitimi ve neoliberal söylem fırtınasında yașayan genç, küçük-burjuva yazarlar olacaktı.

Gençliğinde Muhafazakâr Felsefe Grubu'nun toplantılarına katılan Thatcher, buradaki toplantıların birinde "Bir ideolojimiz olmalı. Diğer tarafın siyasetini sınayabileceği bir ideolojisi var. Bizim de olmalı,"13 diyordu. İktidara geldiğinde solun fikirsel alandaki hegemonyasını kırmak için, liberalizmin muhafazakâr, içine kapalı ve özgürlük karșıtı imajını yenilemeye soyundu. İșçi sınıfı, emperyalizm, devletçilik, eylemcilik gibi sözlerin yerini "piyasanın güçleri, monetarizm, uygun maliyet, bireysel sahiplik, danıșmanlık, yuppiler, özgürlük, arzu, fırsat"14 gibi sözler alırken, Demir Leydi'nin aforizmaları kulaklarda çınlıyordu: "Toplum diye bir șey yoktur. Tek tek kadınlar, erkekler ve aileler vardır." ${ }^{15}$ Geleneksel kurumların savunulmasından ve sürdürülmesinden yana olan ve 2. Paylașım Savașı sonrasında tedavüle giren eski muhafazakârlık söyleminin aksine bireye, özgürlüğe ve özgür seçime vurgu yapan bu neoliberal dogma için özgürlüğün tek garantisi piyasa oldu.

Özetle, burjuvazi yeni saldırısını söylem düzeyinde de örgütle-

\footnotetext{
${ }^{13}$ Hugo Young. One of Us: A Biography of Margaret Thatcher (London: Pan Books), s. 406'dan aktaran D. Keith Peacock. Thatcher's Theatre: British Theatre and Drama in the Eighties. (Greenwood Press, 1999), s. 11. Thatcher dönemi tiyatrosu üzerine yazdığım paragraflar büyük oranda Peacock'un bu çok bașarılı çalıșmasına dayanmakta.

${ }^{14}$ A.g.e. s. 6 .

${ }^{15} \mathrm{http}: / /$ briandeer.com/ social/thatcher-society.htm (24 Ağustos 2008 tarihinde indirildi).
} 
mekteydi. Refah devletinin 1970'lerdeki krizine değin, kapitalizmin mağdurları olan dar gelirliler ve ișsizler devrimci bir tehdide dönüșmemeleri için devlet tarafından kollanırken, Sovyetler Birliği'nin devrimci siyaseti terk etmesiyle ve dünyadaki devrimci kalkıșmaların çeșitli yerlerde yenilgiye uğramasıyla tavır değiștiren kapitalizm, yeni söyleminde ezilenleri artık "beleșçiler" yahut "kendi ahlaki yetersizliklerinin kurbanı" olan insanlar diye niteliyordu. Thatcher'ın 1979'daki seçim sloganlarından birisi, "hem EP'ye hem de ișçilere gönderme yaparak labour doesn't work" (hem "emek çalıșmıyor" hem de "Emek Partisi ișe yaramaz" diye çevrilebilir) diyordu. Birey-toplum diyalektiğine ilișkin fikirlerin yıpratılması bir yandan devam ederken, Thatcherizm, ișbirliğini de sermayenin çıkarları doğrultusunda örgütlüyordu. Neoliberalizm tüketim alanında bireycilik ve özgür seçimi pompalarken, "ahmaklar" (ing. loon) dediği solcuların emek-sermaye çelișkisinden bahsetmesine içerliyor ve Demir Leydi'nin ağzından șöyle diyordu: "Bana bir șirketteki 'onlar' ve 'biz'den bahsetmeyin. Bir șirkette herkes 'biz'dir. Siz șirket var oldukça varsınız, șirket zenginleștikçe zenginleșirsiniz - hep birlikte. Gelecek ișbirliğindedir, çatıșmada değil."16

Britanya'da tiyatronun 1960'lar ve 1970'lerde devlet tarafından desteklendiğini ve bunun da tiyatronun halka ulașmasında önemli bir katkısı olduğunu öğreniyoruz. Yukarıda bahsettiğimiz sosyalist tiyatrolar ve yazarlar da böyle bir ortamda çiçeklenmișlerdi. Ne var ki 1979 yılıyla birlikte neoliberal saldırının hızla sanatı da özelleștirmeye soyunduğunu görüyoruz. Neoliberaller devlet destekli tiyatronun rekabeti ortadan kaldırdığını ve kaliteyi düșürdüğünü savunuyor, SSCB'nin sanat politikasını öcüleștirerek yeriyor ve bu alanda da serbest piyasanın tek çözüm olduğunu savunuyorlardı. "İcraatları" sadece söylem düzeyinde de kalmadı, 1981 yılında, 35 yıldan sonra ilk kez, Sanat Konseyi denilen kurum, bütçe yetersizliği nedeniyle büyük kesintiler yapmak zorunda kaldı. Böylece sanat kurumundan destek alan 41 girișim -ki bunların 18'i tiyatrolardı- ödeneksiz bırakıldı. ${ }^{17}$ Sanat ve tiyatro özel firmalardan bulunan sponsorluklara yaslanmak zorunda kalırken, bu sponsorları ikna edebilmek ve seyirci çekebilmek için daha "Iımlı" eserler sahnelemeyi seçiyorlardı. Elbette bu yeni düzenin tiyatroların örgütlenmesine büyük bir etkisi oldu. Peacock'tan olduğu gibi aktaralım: 
[B]unun siyasi bir etkisi oldu. [Bu tiyatrolar] ya yönetim biçimlerini değiștireceklerdi ya da sponsorlarını kaybedeceklerdi. Tiyatro aracılığıyla kapitalist bir müessese idaresinin özellikleri -muhasebe, maliyet analizi ve maliyet azaltma, ölçülebilir amaçlar, pazarlama, tahmin, verimlilik, insani ve maddi kaynaklar ve ödenek arttırmaya ilișkin pahalı kurslarla birlikte, görünüște hazır bulundurulan danıșmanlar-ve o sıralar ödenekli tiyatrolar için yabancı olan bir söylem içeri sızdı. Bu türden faaliyetler dikkat istiyordu ve sanat yönetmenlerinin enerjisini, varoluș nedenleri olan yaratıcı süreçlerden, șirket idaresine çekti. Max Stafford "Ben artık zaman zaman oyunlar sahneleyen bir ticari müessese ișletiyorum," diyordu acı acı... ${ }^{18}$

Devlet böylece oyunlara bilindik türden bir siyasi sansür uygulamıyor, tiyatroyu burjuvazinin merhametine bırakarak ekonomik bir sansür mekanizması inșa ediyordu. Neoliberalizmin sendikalara ve ișçi mücadelesine vurduğu darbe, benimsediği popülist söylemle birleșince siyasi tiyatronun dayanabileceği bir taban da kalmadı. Bu durumda tiyatronun var olabilmek için siyasi bir dönüșüm geçirdiğini, bu alanın giderek sosyalist yazar ve kumpanyalardan temizlendiğini söylemeye gerek var mı bilmem. Neoliberalizm siyasi tiyatronun parasal kaynaklarını, apolitikleștirdiği seyirci kitlesiyle birlikte yok etti.

Siyasi tiyatronun bu süreçteki dönüșümü traji-komiktir. 1970'lerin sosyalist tiyatroları, 80’lerle birlikte dikkatlerini feminizme, eșcinsellere ve ülkedeki azınlıklara yöneltmeye bașladılar. Bilinç așınmasının bir sonucu olarak, eleștirinin bütünlüklü odağı salt üstyapısal bazı arızalara ișaret edecek biçimde saptı ve sosyalist söylemin yerini liberal söylem aldı. Neoliberal proje kapitalist ve emekçi düșmanı olduğu için değil de, "otoriter" ve "merkeziyetçi" olduğu için eleștiriliyordu artık. McGrath "sosyalizm kendi insanlık görüntülerini, kötü ve iyi, aziz ve günahkâr stereotiplerini yeniden düșünmelidir,"19 diyordu. Yazar, Edgar ve Griffith'le birlikte (ki üçü de 70'lerin siyasi yazarlarıydı) yeni bir akımın faziletlerini keșfetmeye yöneldi: Karnavalesk tiyatro. Bahtin'in "karnaval" teorisinden 
var ki yeniden keșfedilip piyasaya sürülmesi için ișçi militanlığının ortadan kalkmasını beklemek gerekiyordu) yararlanılarak ortaya atılan bu tiyatro, sınıfsal bakıșın ve devrimci değerlerin yerine, liberalizmin daha suyuna giden, reformist ve hümanist değerleri geçiriyordu. Örneğin 1985 yılında David Edgar'ın bir oyununu yöneten Ann Jellicoe șöyle diyordu: "Siyaset bölücüdür. Eserimizin insani etkisinin siyasi karıșıklık çıkarmaktan çok daha üretken olduğunu güçlü bir șekilde hissediyoruz."20 Böylelikle, 1970lerin devrimci yazarları -Britanya'daki trafik akıșına da uygun olaraksol taraftan Thatcher'ın "emek sermaye yok, biz varız" söylemine yaklașıyor, devrimci safları terk ediyorlardı.

Britanya tiyatrosunu 1990'ların bașında krize sokan da, yazının bașından beri bahsettiğim bu üçayaklı değișim oldu. Öncelikle 1970'lerden sonra hâkim hale gelen ve oyun yazarlığını ikinci plana düșürerek yönetmen tiyatrosunu öne çıkaran fiziksel tiyatro ve performans sanatının göz ardı edilemez yükseliși; ardından Britanya'daki sanatı vuran özelleștirme dalgasıyla tiyatroların kendilerini kapitalist bir rekabetçilik içinde bulmaları; ve nihayet, yitirilen sınıf bilinci yerine burjuvazinin dayattığı bireyciliğin hem seyirciyi hem de sanatçıyı düșürdüğü boșluk. Böylece Britanya'da 1990'ların ortasına kadar süren bir kriz hâsıl oldu. Yönetmenler ünlerine ün katmak için klasik repertuardan oyunlar sahneliyor, tiyatrolar "yeni eserlere destek verip risk almak yerine, popüler klasiklerin" ${ }^{21}$ sahnelenmesini tercih ediyorlardı. IYFT yazarlarından biri olarak görülen Mark Ravenhill bir yazısında bu dönemi șöyle ifade ediyor: "Oyun yazarı figürü her yerden sert darbeler alıyordu. Fiziksel tiyatro, performans eserleri, tasarımlar; bunlar doksanların bașında en "kuul" seçenekler olarak görünüyordu göze."22

${ }^{20}$ Peacock, a.g.e. s. 115.

${ }^{21}$ Graham Saunders. "Introduction", Cool Britannia? British Political Drama in 1990s. Ed: Rebecca D'Monté ve Graham Saunders. (Palgrave Macmillan: 2008). s. 10.

${ }^{22}$ Mark Ravenhill, "A Tear in the Fabric: The James Bulger Murder and New Theatre Writing in the 'Nineties'”, NTQ, cilt. 20. No. 4 (2004), s. 310.
Burjuva ideolojisi gibi burjuva sanatı da, siyasi bilincin öldüğü yere konan bir akbabadır. Ravenhill'in sözlerinden de anlașılacağı üzere, egemen sınıfın sanatı serbest piyasayla kol kola hücum ederek, kadim düșmanı politik tiyatroyu 1990'ların bașıyla birlikte yenilgiye uğrattı; performans sanatı ve fiziksel tiyatro nihayet buradaki gösteri sanatlarının baskın öğesi haline geldi. Apolitikleștirilmiș bir seyirci kitlesinin, apolitik sanattan bașka bir șey tüketmesi beklenebilir mi? Böyle bir ortamda Thatcher'ın çocukları, 
bizdeki darbe çocukları gibi, tüm kafa karıșıklıklarını, karșı çıkışlarını ve yenilgilerini sırtlayıp sözlerini sahneye tașıdılar. Ancak, ișler bu kez bambașkaydı. 1970'lerin aksine, dâhil olunacak bir ișçi sınıfı hareketi, bir dava yoktu ve bașarılı olmak istiyorlarsa eğer, bir yolunu bulup oyunlarına seyirci çekmeleri gerekiyordu.

Artık ayağımızı teorinin toprağına basma vakti geldi.

\section{BurJuVAzinin BitMEyen \\ UMUDU: ĐEĞișint}

Sınıf mücadelesine vurulan darbeyle, sanatın içeriği de hapsedilmiș oluyordu. Böyle durumlarda sanatın izleyeceği yegâne yol vardır, o da biçimciliktir. Bunun öznel ve nesnel olmak üzere, birbiriyle etkileșim içindeki iki sebebi olduğunu söyleyebiliriz. Toplumsal gözün yitirilmesiyle, toplumu șekillendiren unsurun üretim ilișkileri olduğu unutulur, bunun yerini insanın özünün kötücül, hayatın da anlamsız olduğu, yașananların herhangi bir nedenden ya da ilișkiden kaynaklanmadığı bir dünya tasavvuru alır. Sanatçı bazı sonuçların farkındadır; toplumsal ilișkilerdeki düzensizlikten, savașlardan ve akan kandan haberdardır. Ne var ki bunları herhangi bir toplumsal bağlama oturtamaz:

[E]konominin somut sorunlarından genel bir yabancılașma, ekonomi, toplum ve ideoloji arasındaki bağların gizlenmesi ve bunun sonucunda bu türden sorunların giderek artan bir șekilde gizemlileștirilmesi söz konusudur. ${ }^{23}$

Eğer dünyanın durumu böyle teorileștirilirse, bunun bazı düșünsel sonuçları olur. Demek ki dünyada değișime yol açan değil, sürekli aynı șeyin tekrarına neden olan, niceliksel bir devinim söz konusudur. Demek ki dünyadaki ilișkiler düzlemini belirleyen toplumsal bir dinamik yoktur; toplumlar iktidar hırsı, bencillik ve öldürme arzusu gibi insan özüne ait olan, sınıflardan bağımsız, evrensel bir belirleyen tarafından yönlendirilmektedir. O halde, sanat karamsarlığın, değișmezliğin ve "söylenecek yeni bir șey yok"un hatırlatıcısı olmalıdır. Küçük-burjuva sanatçı için tüm ilișkilerde kötülük, bağlamsız șiddet; tüm așklarda yalnızca șehvet,

\footnotetext{
${ }^{23}$ Georg Lukàcs. "Expressionism: Its Significance and Decline", Esssays on Realism, ed. Rodney Livingstone, trans: David Fernbach (Lawrence \& Wishart, 1980). s. 82
} 
${ }^{24}$ Öyle sanıyorum ki sanatçının hamileriyle olan ilișkisindeki bu dönüșümünün ilk etrafı incelemesini yapan Arnold Hauser oldu. Ben de çoğunlukla onun iki temel eserinden, yani Sanatın Toplumsal Tarihi, çev: Yıldız Gölönü (Remzi Kitabevi, 1984) ve The Sociology of Art, çev: Kenneth J. Northcott (Routledge \& Kegan Paul, 1982) adlı bașyapıtlarından yararlandım.

${ }^{25}$ Hans-Peter Bayerdörfer. "Nô in Disguise: Robert Wilson's Adaptation of Nô Elements in His Production of Alkestis/Alceste.", Japanese Theatre and the International Stage, ed. Stanca Scholz-Cionca ve Samuel L. Leiter (Brill Academic Publishers, 2000). s. 369. tüm dostluklarda bir tek tecavüz ve kahpelik vardır. Anlatılacak șeyler hep aynı olduğuna göre, demek ki küçük-burjuva sanatçının ne anlattığı değil, nasıl anlattığı önemlidir. Demek ki içeriğe değil, bir tek biçime kafa yormalıdır. Bu saplantı, biçimciliğin öznel, yani bilince ilișkin yanını olușturur.

Biçimciliğin nesnel kaynaklarını ise üretim ilișkilerinde buluyoruz. Kapitalizmin hâkim üretim biçimi haline gelișinin sanattaki etkileri üzerine yazan Hauser, toplumsal alandaki dönüșümün, sanat alanında da ister istemez niteliksel ve köklü bir değișime yol açtığını söylüyor. Feodalizme ve merkantilizme has hamilik kurumu on sekizinci yüzyılın ikinci yarısıyla birlikte ortadan kalkıyor, sanatçıyla müșterisinin arasına kaprisli ve rekabetçi bir piyasa giriyor, bu ilișki kendi aracı kurumlarını yaratıyordu. ${ }^{24} \mathrm{EI}-$ bette, kültürel alandaki etkisini yıkımlar ve yeniden yaratımlarla sürdüren kapitalizm, bir yandan kültürü metalaștııırken, bir yandan sunduğu olanaklarla farklı anlatım biçimlerinin ve tekniklerinin doğmasına da önayak olmuștu. Ancak sanatçı artık intiyaçları ve talepleri o kadar net olmayan bir alıcı kitlesinin karșısındaydı ve rekabet edilmesi gereken bir sürü farklı sanatçı onun varlığın tehdit ediyordu. Sanatçı bu noktada bir dizi piyasa silahını tedavüle sokmak durumunda kaldı: Deha, orijinallik, sanatıyla tabuları yıktığı iddiası, seyirciyi sarsma vb. Bunların bazıları, mesela deha fikri, çok uzun yașayamadı ama seyirciyi sarsma ve tabuları yıkma iddiası Fütüristlerden bu yana varlığını korudu. Ne zaman yeni bir tür, bir akım ya da bir biçim peyda olsa, sanatta devrim yapıldığını, burjuvazinin tabularının yerle bir olduğunu öğreniyorduk. Benzer bir șablonu IYFT teorisyenleri de kullanıyor.

Her dönemde bu seyirciyi sarsma mitolojisinin en popüler yöntemlerinden biri "kenarlara" nüfuz etmeye çalıșmak oldu. Örneğin șu alıntıya bir bakalım:

[P]olitik ve muhalif tiyatronun 1970'lerin ortasındaki düșüșüne müteakip, tiyatrocular Avrupalı olmayan teatral kültürlere yeni bir bakıș yöneltme ve kültürlerarası ilișkilere yönelik yeni bir yaklașım gösterme eğilimine girdiler. ${ }^{25}$ 
Bayerdörfer'in bu tespitinden politik ve estetik bir gözün alacağı önemli iki șey var. Birincisi, burjuva tiyatrosunun politik tiyatronun hız kaybetmesinin ardından yeni bir sanatsal hammadde arayıșına girdiği; ikincisi de, bu arayıș süreci içinde Avrupa dıșına, yani o bahsettiğimiz "kenar"a nüfuz etmeye çalıștığı. Taze biçimler ve yeni fikirler büyük bir hızla Batı'ya pazarlanırken, çokkültürlülük gibi güzel bir de isimle etiketlendi. IYFT örneğinde de benzer bir durumla karșı karșıyayız. Can çekișen politik tiyatroyla birlikte oyun yazarlığının da düșüșe geçmesiyle olușan kriz, BritanyaIı yazarları da Britanya toplumunun kıyılarında sürülen karanlık yașamları aramaya itti. ${ }^{26}$ Benim kenarlara nüfuz etme çabası dediğim durumu, Georg Lukacs "psikopatolojiye kaçıș” olarak adlandırmıs ve bu tür edebiyatta psikolojik rahatsızlıkların, sapıklıkların ve maraziliklerin "insan varolușunun normal durumu; sanat ve edebiyatın asıl araștırma alanı, olușturucu ilkesi" ${ }^{27}$ haline geldiğine dikkat çekmiști.

IYFT'yi daha iyi analiz edebilmemiz için, onun belli bașlı kimi özelliklerini ortaya koymamız gerekiyor. Bu meseleye ilk kafa yoran yazar Aleks Sierz olduğu için, bașlarken ona dönmek faydalı olabilir, IYFT'nin özelliklerini dört madde altında topluyor Sierz: (1) Açık cinsellik ve șiddet sahnelerinin varlığı. Anal tecavüz, çocuk istismarı, uyușturucu kullanımı, yamyamlık ve kusma temsilleri, (2) Tabuların yıkılmasına duyulan ilgi, (3) Seyirciyi sarsma ve sahnede olan bitene kayıtsız kalamamasını sağlamaya çalıștığı için deneysel olması ve (4) IYFT'nin içeriği ve biçimi farklı da olsa, selefleri gibi politik olduğu iddiası. ${ }^{28}$

Burjuva ahlakının ve burjuvazinin tabularının niteliğine ilișkin önemli bir yanılgıyı açımlayarak bașlayalım. Max Weber'in 20. Yüzyılın bașında Protestan ahlakına ilișkin yaptığı çözümlemelerin ardından, burjuva ahlakına ilișkin anlayıș sanki donmuș bir vaziyette. Buna göre burjuva ahlakı para kazanmak için tüm zevklerinden fedakârlık eden, tüketime sırt çevirmiș ve tüm kârını yeniden üretime yatıran kapitalist bireyin ahlakıdır ve daima muhafazakardır. Burjuvazinin dinsel dogmalara olan katı bağlıı̆̆ı, onu bedensel zevklerden uzak tutar; dolayısıyla kapitalist çalıșır, çalıșır ve yine çalıșır. Bu anlayıș daha Weber'in zamanında eskimiști ve burjuva ahlakının değișken niteliğini anlamaktan uzaktı.

\footnotetext{
${ }^{26}$ Aleks Sierz, "Still In-Yer-Face? Towards a Critique and a Summation.", NTQ 69 (Șubat 2002): 17-24 adlı yazısında, IYFT yönetmenlerinin bu tavrını șöyle ifade ediyor: "Yeni yazarlara cehenneme gidip orada bulduklarını rapor etme iznini verdiler hiçbir ideolojik önyargıları olmaksızın." Sanja Nikcevic de, görüșümü doğrular bir biçimde șöyle diyor: "Yeni Avrupa Dramı, yalıtıımıș gruplașmaları sunma eğilimindeydi. Genellikle marjinalize edilmiș dünyaları tek olası dünya gibi gösteriliyordu. Uyușturucu bağımlıları, fahișeler, ensest ilișkide bulunulan aileler, deli ya da kayıp karakterler merkeze alınıyordu." Bkz: "British Brutalism...", s. 269

${ }^{27}$ Georg Lukács. Çağdaș Gerçekçiliğin Anlamı, çev: Cevat Çapan. (Payel Yayınevi: 2000), s. 38.

${ }^{28}$ Sierz, a.g.y. s. 19.
} 
Thatcher rejiminin yaptığı propagandadan bahsederken de belirttiğim üzere, özellikle neoliberal politikalarla birlikte tüketimin önündeki tüm ahlaki engelleri kaldırmak için burjuvazi siyasi mücadelenin yanında sert bir ideolojik mücadele yürütmekte. Artık burjuva ahlakının Weber'in bahsettiği Protestan ahlakıyla pek az ortak yönü kalmıștır. Asalak kapitalizm, piyasanın krize girmesinin altında yatan üretim fazlasını, tüketimi özendirdiği yeni ahlakıyla așmaya çalıșıyor. "Özgür" birey kapitalizmi tehlikeye düșürmediği sürece istediği yola sapabilir. Üretimin kolektifliğine yapılan vurgu, tüketimin bireyselliğine kaymıș, bireylik bilinci sınıf bilincinin yerine geçirilmiștir. ${ }^{29}$ Sermaye tabular ve ahlak da dâhil olmak üzere, tüm araçları gereken yerde ișe koșacak, gereken yerde de ortadan kaldıracak kadar akıllıca hareket ediyor. Demek ki kapitalizmin temeline ve emek sermaye çelișkisine değinmeksizin, kimi kültürel ve sanatsal tabuları yıkmaya debelenmek, sistemin yıpratılmasına değil, aksine güçlendirilmesine yarıyor. Sanatçı, kentsel dönüșüm için gecekonduları yıkan belediye ekipleri gibi, burjuva kültürünün neoliberal toplumun gerekliliklerine uyum sağlayabilmesi için gecekondulașmıș tabulara ve ahlak anlayıșlarına saldırıyor ve böylece bir tașeronluk görevi üstleniyor, bilerek ya da bilmeyerek.

${ }^{29}$ Zygmunt Bauman. Consumerism and the New Poor. (Open University Press: 2005), s. 23-41.
Alfred Jarry'den bu yana burjuva seyirciyi sarsma isteğinin en önemli aracı șiddet oldu. Sahneden seyirciye küfretmek, sövmek, seyirciyi așağılamak marifetiyle onun oyuna kayıtsız kalmasını engellemek gibi amaçlar İkinci Paylașım Savașı'ndan sonra biçim değiștirdiler. Seyirciyi sarsma amacı yine aynı kaldı, fakat bu kez bedenlești: Artaud'nun vahșet tiyatrosunun bedene ve kan dökmeye ilișkin bir șey olmadığını vurgulamasına rağmen, onun müritleri giderek sözden bedene doğru yöneldiler. Performansın ve fiziksel tiyatronun sahnesi giderek çıplak bedenlerle, ișkencelerle, kanla ve acıyla kaplanmaya bașladı. Sanki seyirciyi etkilemenin tek yolu onun iğrenme, çekinme, korkma, șașırma duyguları üzerinde spekülasyon yapılmasından, bunun yolu da oyuncu ya da performans sanatçısının kendine acı vererek rol yapmadığını kanıtlamasından geçiyordu. Kapitalizmin ve onu yıkacak güçlerin akılcı bir analizi seyirciye sunulmadığından, bu tür sanatla burjuvazinin pek derdi yoktu. 
IYFT elbette bulunduğu coğrafyanın hâkim estetik anlayıșından, yani performans sanatının mazoșist bedensel vurgusundan etkilendi. Mark Ravenhill'in, Shopping and Fucking [Alıșveriș ve Sikiș, 1996] oyununda oyun kișileri henüz reșit olmamıș bir oğlana bıçakla anüsünden tecavüz ederek öldürüyorlar, Sarah Kane'in Blasted adlı oyununda tecavüz, anal tecavüz ve yamyamlık ön plana geçiyor; yazarın Phaedra's Love [Fedra'nın Așkı, 1996] adlı oyununda sahne üzerinde oral seks ve parçalanan bedenler gösteriliyor; Anthony Neilson The Censor [Sansürcü, 1997] adlı oyununda porno filmlerin inceliğini tartıșıyor ve Normal [1991] adlı oyununda bir cinayet sahnesini seyirciyi sarsacak kadar uzun bir süre ișliyordu. Elbette IYFT sahnesinin Body Art (Bedensel Sanat) nevinden sahici bir șiddet arayıșında olduğunu söylemiyorum; Britanya'da sahnede oyuncunun yașamını riske sokacak eylemlerde bulunulması yasaktır, ancak oyuncuların belirli bir sahiciliği yakalamadan seyirciyi etkilemesi zor olduğu için, gerçeğe yaklașma çabasının varlığı ve Body Art etkilenimi göz ardı edilemez.

Peki acaba șiddet, tecavüz, cinayet vb. gibi eylemlerin sahnelenmesi, kayıtsız șartsız bir ilericilik ya da gericilik olarak anlașılabilir mi? Sahne üzerinde șiddet temsili, bir tiyatroyu "politik" tiyatro yapar mı? Sahne, malzemesini dünyadan alır, öyleyse kendisinin ne içerikte ne de biçimde hayata dair șu ya da bu öğeyi kullanmaması söz konusu olamaz. Burada eleștirilmesi gereken nokta, burjuva sanatçının hayata dair kimi olguları sanatına alırken bunların toplumsal bağlamlarını yok sayması, yalıtması ya da gizemlileștirmesidir. Devrimci tiyatrocu Augusto Boal, bunun sonuçlarını șöyle açıklıyor:

Televizyondaki șiddetin sanatla değil, terörizmle ilgisi vardır; öncelikli hedefi, hayali ya da gerçek tehlike odakları yaratıp, bir yandan da onun kökenlerini gizleyerek genel bir güvensizlik sağlamak, biçimsiz bir korkunun tohumlarını atmaktır. . İzleyicide hasara yol açan șey per se șiddet değil, bu fiziksel faaliyetin bir mantığının olmayıșıdır. Fiziksel eylemlerin mantıksal temelleri yoksa, Empati saf bir akıldıșılık tașıyan bir hayvansallığa Oppressed, çev: Adrian Jackson. dönüșür... ${ }^{30}$ 
IYFT öğeleri tașıyan oyunlar șiddeti büyük oranda Boal'in bahsettiği biçimde kullanmakta. Örneğin Sarah Kane, Blasted adlı oyununda șiddetin kaynağını tarafları belirsiz bir savaș olarak gösterir. Tam da Boal'in dediği biçimde oyun kișileri biçimsiz bir korkunun ortasında paramparça olmușlardır ve bir sonraki darbenin nereden geleceğini bilemezler. Oyun sahnelendiğinde eleștirmenlerin oyundaki savașı Bosna Savașı'na yapılmıș bir atıf olarak algıladıklarını öğreniyoruz. Ne var ki, Kane'in oyununu okuyan kișinin savașa dair yeni bir akıl yürütme biçimiyle karșılașması, yeni bir șey öğrenmesi söz konusu değil: Savaș kötüdür. Peki politik tiyatronun bunun ötesine geçmesini beklemek çok mu fazla șey istemek olur? Savașın kaynağını, yani emperyalizmi gizemlileștirip, bir olgu olarak savașı tümden reddetmemiz durumunda, halkların dağlarda ve kentlerde özgürlük için verdikleri mücadeleleri de karalamıș olmuyor muyuz?

Durum böyle olunca, IYFT'nin politik olduğu iddiası da tökezliyor. Elbette politik sanatın tek yolu Trevor Griffiths'in The Party [Parti, 1973] oyunu gibi sahne üzerinde Marksizm-Leninizm teorisini tartıșmak değil. Aksine, bilinçlendirilmek istenen seyirci kitlesinin dertlerine odaklı olan ve sorunları, bunların kaynaklarını belirsiz kılmadan ele alan bir politik tiyatroda meta-teori tartıșmalarına pek fazla yer yoktur. IYFT'de seyircinin ve okurun tanık olduğu ise toplumsal bir șiddet değil, estetik bir șiddettir. Yani, hiçbir iktidar odağına değmeksizin, akılla ve toplumla kesișmekten kesinlikle kaçınarak, șiddeti seyirciyi empati duygusundan vuracak ve böylece oyunu ilginç kılacak bir teatral meta olarak kullanmaktan bahsediyorum.

Bu tür bir șiddet algısının kaynağı, burjuva ideolojisinin kıvrımlarında saklı aslında. Thatcher'ın çocukları șiddettin toplumla olan bağını kurmak konusunda hevessizler. Bölüm bașında belirttiğimiz üzere, bu oyun yazarları sistemdeki yanlıșlığın kaynağı görmezden geldiklerinde, sorun ister istemez insan olmaya ilișkin bir soruna ("șiddet insanın özüdür") ya da evrensel kozmik bir bilinemezliğe ("Tanrı bizi terk etti”) havale ediliyor. Șiddetin temsili iște bu söz konusu özün temsili oluyor böylece. Onun toplumsal bağlama oturtulmasına gerek yok, çünkü yazara göre zaten toplumsal bir olgu değil. 
John Fraser, 1974 yılında yazdığı Violence in the Arts (Sanatlarda Șiddet) adlı kitabında önemli bir tutuma dikkat çekiyor. Șiddet anlayıșının toplumsallıktan böylece yalıtılmasının onu insanın özüne mal etmede bir taktik olarak kullanıldığına vurgu yaparak șunları söylüyor Fraser:

Demek ki șiddetle dürüst bir șekilde hesaplașan sanatçı... seyircinin burnunu uzlașılmaz olana sürten ya da insanlığın, en azından günahkâr burjuvazinin özündeki kirliliğe, yaramazlığa ve canavarlığa ayna tutarak seyirciyi düșündüren biridir... Bu nedenle, bu türden çalıșmalar karșısında çekinceler ifade etmek kișinin kendi entelektüel güçsüzlügünü ortaya çıkarır. Kiși demek ki varoluș hakkındaki belirli felsefi hakikatlerle yüzleșmeye dayanamıyordur. Kiși sanatçının "ürkütücü dürüstlüğüne" katlanamıyordur. ${ }^{31}$

Hiç de șașırtıcı olmayan bir biçimde, Fraser'dan 25 yıl sonra IYFT teorisyenleri ve yönetmenleri kendilerini eleștirenlere ortak bir cephe açarak benzer bir kalem savașına girdiler. Bu tür oyunlara getirilen eleștirileri göğüslemek için geri kafalı, anlayıșsız gibi ithamlar biricik savunma silahları oldu. Oyunları eleștirmeye cüret edenler "burjuva, bezgin, sinik" olmakla suçlandı, bu türden oyunlara sempati beslemeyenler "korkak" olarak etiketlendi. ${ }^{32}$ $\mathrm{Bu}$ herhalde absürd tiyatrodan beri kullanılan bir karșı saldırı yöntemi olsa gerek.

IYFT'nin politik olduğu iddiaları (ki, bu iddiaların seyirci çekme yarıșında önemli rol oynadığını da unutmamak gerek), sanırım en güzel Brecht'in gestus (toplumsal jest) kavramı üzerinden göğüslenebilir. "Jestsel Müzik Üzerine" adlı yazısında Brecht, "toplumsal jest nedir?" diye sorar. Sosyalist sanatçının amacı, oyun kișisinin sınıfsal konumuyla, yașadığı çevre ve zamanla sıkı sıkıya bağlı bir jestsel ifade yaratmaktır. Eğer kișinin yașamında toplumsal ilișkiler belirleyici rol üstleniyorsa, ait olduğu sınıfın ve zümrenin tavırları oyun kișisinin üzerine sinmiș olmalıdır. Șöyle yazar Brecht:

Tüm jestler toplumsal jest değildir... Kișinin kaygan bir yüzeyde dengede kalma çabası, eğer düșmek [kendisi için] "rezil rüsva olmak" anlamına, diğer bir
31 John Fraser. Violence in the Arts. (Cambridge University Press, 1974), s. 109-110.

${ }^{32}$ Nikcevic, a.g.y., s. 260, 262. 
değișle, kișinin piyasa değerini yitirmesi anlamına gelecekse toplumsal bir jesttir... toplumsal jest toplumla ilișkili jesttir, kendisinden toplumsal șartlarla ilgili sonuçlar çıkarılmasını sağlayan jesttir. ${ }^{33}$

Șiddet meselesinde de benzer bir șeyi söylemek mümkün. Sahnede bir șiddet eylemi temsil edildiğinde, bunun nedenleri sezdirilmezse, bundan yola çıkarak toplumsal ilișkilere dair daha geniș bir tasvirin yolu açılmazsa geriye güdük ve estetikleștirilmiș bir șiddet kalır. Ticari sinemanın da çok sevdiği, aksiyon sahnelerinin vazgeçilmezi olan șiddet, seyirci çekmek için en çok kullanılan yöntem olsa gerektir.

Șiddeti, belirsiz bir kaynaktan fıșkıran bir eylem olarak sanatlaștırdığınızda bunun politik olduğu muhakkak. Ne var ki, sorun, sanatçı bunu ilerici bir politika olarak göstermeye çalıșınca çıkıyor. Toplumsal düzlemde belirsizlik, nedensizlik ve amaçsızlık küçükburjuvazinin politika anlayıșıdır. Elbette hep olduğu gibi, "politik tiyatro" gibi bir ifade de dönemin hâkim siyaset anlayıșından etkilenerek her türden çarpıtmaya açık hale geliyor. Sahne üzerinde anal seks yapılmaz, tecavüz gösterilmez ve kusulmaz gibi tabular, var olan iktidar ilișkileriyle bağlantılandırıldığında politik olma özelliğini, bu bağlantılar da doğru yapılırsa eğer, ilerici olma özelliğini kazanırlar. IYFT'de zaman zaman kimi bağlantılar kurulsa da, bunların yanlıș yapıldığını görüyoruz. Ancak çoğunlukla tanık olduğumuz șey, Kane'in Phaedra's Love oyunundaki gibi, toplumsallıktan yalıtımıș bireylerin hastalıklı ilișkileri oluyor.

${ }^{33}$ Bertolt Brecht. "On Gestic Music", Brecht on Theatre, ed. ve çev: John Willett. (Methuen Publishing: 2001), s. 104-105.
Değișimi tekrara, toplumu bireye indirgemek ve bireyin de özünde șiddet ve yıkım olduğunu savunmak IYFT'nin en temel özelliklerinden birisi. Sözlü ve fiziksel șiddetin yoğun ve doğalcılığa yaklașan kullanımı, metinlerin dramatik yapısı ve söz ağırıklı olușu beni IYFT'nin teorik kaynaklarını tekrar düșünmeye itti. Pek çok IYFT teorisyeninin aksine, temel kaynağın Artaud'nun tiyatro anlayıșı olduğundan o kadar emin değilim. IYFT kesinlikle sürrealizmin ağır bastığı bir eğilim değil. Kendisini etkileyici kılabilmek için gerçekçi, ayrıntıcı bir șiddet temsiline yaslanırken bir yandan da müthiș bir indirgemecilikle, yalnızca șiddetin, yalnızca 
marjinal yașamların öykülenmesiyle ilgileniyor ve çoğu zaman bu öykülemeyi de gerçekçi bir șekilde ișliyor. Sahnede sadece șiddetin temsil ediliyor olması, onu Artaudcu tiyatroya yaklaștırmaya yetmiyor.

Tüm bunlardan yola çıkarak, IYFT'nin büyük oranda doğalcılığın mirasını sürdürdüğü söylenebilir. Bu yönün eleștirmenler tarafından çoğunlukla görmezden gelinmesini ben "Artaudcu tiyatro" imajının "Zolacı tiyatro" imajından çok daha fazla pazarlanabilir olmasına yoruyorum. Diğer yandan IYFT'nin savunucularının benimsediği argümanlardan birisi de, muhafazakâr tiyatronun korkaklığının aksine, sahnede șiddetin gerçekçi temsilinin cesurca bir hareket olduğudur. Çünkü, derler, IYFT gerçekliği daha dürüst bir șekilde seyirciye gösterir. Bununla birlikte, gerçekçiliğin bir eylemin yalıtımıș temsilinde değil, o eylemin toplumsal ilișkiler ağı içindeki temsilinde yattığı görmezden gelinir. Bunun sonucu kaçınılmaz olarak bir șiddet doğalcıı̆̆ı olur.

IYFT'nin doğalcılık eğilimine, konuya ilișkin bașka bir yazımda değinmiș, dünyanın seçme yapılmaksızın sahneye getirilmeye çalıșılmasının sebep olduğu sonuçlardan bahsetmiștim. Diyalektik anlayıștan yoksun bir sanatçı, toplumsal ilișkilerde belirleyen öğenin ne olduğunu kavrayamadığı için, hayatı tamamen bir tesadüfler silsilesi olarak algılamaya yatkındır. Bu nedenle șu ya da bu öğenin seçilip vurgulanması, herhangi bir noktaya özellikle dikkat çekilmesi ona göre anlamsız olacaktır. Çatışan güçlerin tesadüfîliği dönüșüme dair herhangi bir umudu da geçersiz kılar. Bunun IYFT'deki tezahürü, belirttiğimiz üzere toplumsal ilișkiler düzleminde hissedilir. Oyun tiplerinin bağlı olduğu herhangi bir sosyo-tarihsel bağlam bulunmazken (indirgemecilik), sanatçı tüm enerjisini ve kurgusunu șiddetin gerçekçi temsiline harcar (doğalcıılı). ${ }^{34}$

Böylece IYFT neredeyse tüm öğeleriyle bir değișim karșıtığına soyunur. Kötüler evreninde iyiye dair ne varsa ya sahnede kendine yer bulamaz ya da boğulup ölür. Değișim karșitı her sanat yapıtında olduğu üzere, karamsarlık oyun evreninin vazgeçilmez bir bileșenidir. Öyleyse Sierz'inkileri değil de, kendi IYFT tanım-

${ }^{34}$ Bu paragraftaki doğalcılık eleștirisi esasen Georg Lukács'a ait. Benim burada yaptığım IYFT oyunlarını Lukács'ın eleștirisi üzerinden değerlendirmek oldu. Bkz: Georg Lukács. Çağdaș Gerçekçiliğin Anlamı. 
lamamızı getirsek bu eğilimi daha doğru yansıtabiliriz: (1) Emekçi sınıfın siyasetine yönelik bir ilgisizlik, (2) Yalnız ve yalnız patolojik ve adli vakalara, sapkınlıklara duyulan ilgi, (3) Șiddeti yaratan toplumsal ilișkilere değinmeksizin yapılan doğalcı șiddet temsili, (4) Anti-komünist tabular dıșındaki tabuları yıkmaya yönelik bir heves, (5) Biçimcilik.

\section{SONUÇTA}

Elbette daha IYFT üzerine yazılıp söylenecek bir sürü șey var. Örneğin bu eğilimin dramatik tiyatro ve metne dayalı temsillerin ölümünün ilan edildiği bir dönemde ortaya çıkıșı ve büyük bir ilgi görmesi, üzerinde durulmaya değer bir konudur. Yine bu eğilimin ticari bașarısının Avrupa'daki oyun yazarlığında yol açtığı ilginç sonuçlara dikkat çekilebilir. IYFT 2000 yılında, Britanya'daki hızı kesildiğinde, Kıta Avrupası'ndaki turuna çıkmaya hazırlanıyordu ve burada o kadar büyük bir ilgi gördü ki, Alman yönetmen Ostermeier "Alman Ravenhill'i kim?"35 diye sormaya bașladı. Özetle, özgün bir eğilim olarak doğan IYFT'nin yükseliși, onun kısa sürede "kârlı oyun yazma rehberi"ne dönüșüp norm haline gelmesine neden oldu. Bașlangıçta yazar tiyatrosunun geri dönüșü olarak lanse edilse de, IYFT öğeleri tașıyan oyunlar bir süre sonra rekabet piyasasının baskısı nedeniyle yönetmenler ve tiyatro yöneticilerinin süpervizörlüğünde yazılmaya, oyunların șurasına burasına tecavüz, fiziksel șiddet, cinsel ilișki sahneleri serpiștirilmeye bașlandı. Çünkü seyirciyi çeken yükselen "trend" artık bu olmuștu.

${ }^{35}$ Nikcevic, a.g.y., s. 262.

Karanlıkta el yordamıyla yürüyenler, aydınlıkta ilerleyenlerden her zaman daha șanssız olsa da, bu hiçbir șekilde doğru yola sapamayacaklarını göstermez. Aksine içinde bulundukları tedirginlikte çok daha fazla ayrıntıyı ısı̆g çıkarabilirler. Yazı boyunca IYFT eğiliminin küçük-burjuva özünden dem vurmuș olsak da, bu vardıkları kimi doğruları gölgelememeli. Örneğin Ravenhill'in Shopping and Fucking adlı oyunu, eleștirel gerçekçilik tonları tașıyan bir oyundur ve el yordamılla olsa da neoliberal saldırı altındaki gençliğin alıșveriș ve cinsellikten ibaret kalan yașamına dikkat çeker, bunu yaparken ("doğru yoktur" diye tepinen liberallerin aksine) ahlaki yargılarda bulunmaya korkmadığını açıkça 
belirtir. ${ }^{36}$ Ravenhill, Kane, Butterworth ve Neilson gibi yazarların dilinden ve kurgusundan hiçbir șey değilse bile, sahici diyalogun, duruluğun, yaratıcılığın ve çarpıcılığın teknikleri öğrenilmeli ve bu teknikler devrimci bir tiyatronun hizmetine koșulmalı diye düșünüyorum. IYFT'nin, son tahlilde kesif bir bireyciliğe hapsolmuș ve herhangi bir siyasi yönelimden kesinlikle uzak duran happening ve body art gibi performans sanatı girișimlerinden çok daha çaplı ve anlamlı olduğu ortadadır.

IYFT'nin öyküsünün tarihsel ve teorik olarak en ilgimi çeken yönü, Türkiye'deki tiyatro hareketiyle kurulabilecek olan paralelliği oldu. Toplumsal ve ideolojik zeminini yitirdiği anda sanatçının kaçış çizgilerinin iki ülkede de bu kadar belirgin, bu kadar șablonvari olması öğreticidir ve hem sanatçıya hem de tarihçiye siyasi tercihlerinin ne kadar kendisine ait olduğunu sorgulatmalıdır. Sınıf siyasetine duyulan isteksizlik, sanatçının aniden bireyliğini keșfediși ve teorisyenlerin metinleri birbiri üzerinden okumak için duyduğu sonu gelmez istek, aslında egemen sınıfın saldırısına yenik düșmek ve teslimiyeti kabullenmektir. Günün koșulları, bir eliyle halkın elini, bir eliyle de sanatını sımsıkı kavramıș, (öz) eleștirel algısı sürekli açık, hem sanatçı hem de inatçı insanlar gerektiriyor. Mücadele sadece ișçiyi ve köylüyü değil, militan sanatçıları da yanına çağırıyor. Katledilenlerin kanı yerde kalmasın, sivri ve öfkeli kalemlerimize mürekkep olsun hiç değilse. 


\section{EREN BUĞLALILAR}

\section{Kaynakça}

Ahmad, Aijaz. In Theory Classes, Nations and Literatures. (Verso: 1992)

Baumann, Zygmunt. Work, Consumerism and the New Poor. (Open University Press: 2005)

Bayerdörfer, Hans-Peter. "Nô in Disguise: Robert Wilson's Adaptation of Nô Elements in His Production of Alkestis/Alceste.", Japanese Theatre and the International Stage, ed. Stanca Scholz-Cionca ve Samuel L. Leiter (Brill Academic Publishers: 2000)

Berghaus, Günter. Avant-Garde Performance: Live Events and Electronic Technologies. (Palgrave Macmillan: 2005)

Boal, Augusto. Aesthetics of the Oppressed. çev: Adrian Jackson. (Routledge: 2006)

Brecht, Bertolt. Brecht on Theatre, ed. ve çev: John Willett. (Methuen Publishing: 2001)

Carlson, Marvin. Performance: A Critical Introduction. (Routledge: 2006)

Cliff, Tony ve Donny Gluckstein. The Labour Party: A Marxist History. (Bookmarks: 1996)

Fraser John. Violence in the Arts. (Cambridge University Press, 1974)

Hauser, Arnold. Sanatın Toplumsal Tarihi, çev: Yıldız Gölönü (Remzi Kitabevi: 1984)

Hauser, Arnold. The Sociology of Art, çev: Kenneth J. Northcott (Routledge \& Kegan Paul: 1982)

http://briandeer.com/social/thatcher-society.htm (24 Ağustos 2008 tarihinde indirildi)

Kane, Sarah. Blasted. (A\&C Black: 2003)

Kane, Sarah. Phaedra's Love. (Methuen Modern Plays: 1996)

Lehmann, Hans-Thies. Postdramatic Theatre. Çev: Karen Jürs-Munby. (Routledge: 2006).

Lukács, Georg. "Expressionism: Its Significance and Decline”, Esssays on Realism, ed. Rodney Livingstone, trans: David Fernbach (Lawrence \& Wishart: 1980)

Lukács, Georg. Çağdaș Gerçekçiliğin Anlamı, çev: Cevat Çapan. (Payel Yayınevi: 2000)

Mark Ravenhill, "A Tear in the Fabric: The James Bulger Murder and New Theatre Writing in the 'Nineties'”, NTQ, cilt. 20. No. 4 (2004)

Neilson, Anthony. Plays 1. (A\&C Black: 2003)

Nikcevic, Sanja. "British Brutalism, the 'New European Drama', and the Role of the Director”, NTQ 21:3 (Ağustos: 2005)

Peacock, D. Keith. Thatcher's Theatre: British Theatre and Drama in the Eighties. (Greenwood Press: 1999)

Ravenhill, Mark. Shopping and Fucking. (A\&C Black: 2003)

Saunders, Graham. "Introduction", Cool Britannia? British Political Drama in 1990s. Ed: Rebecca D'Monté ve Graham Saunders. (Palgrave Macmillan: 2008) 


\section{IN-YER-FACE: TARIHSEL VE TEORIK BIR INCELEME}

Shepherd, Simon ve Mick Wallis. Drama/Theatre/Performance. (Routledge: 2004)

Sierz, Aleks. "The Politics of In-yer-face Theatre", Cool Britannia? British Political Drama in 1990s. Ed: Rebecca D'Monté ve Graham Saunders. (Palgrave Macmillan: 2008)

Sierz, Aleks. In-Yer-Face Theatre: British Drama Today (Faber: 2001)

Stourac, Richard ve Kathleen McCreery. Theatre as a Weapon: Workers' Theatre in the Soviet Union, Germany and Britain, 1917-1934 (Routledge \& Kegan Paul: 1986)

$$
\text { बैซือง }
$$

